International Journal of Current Microbiology and Applied Sciences ISSN: 2319-7706 Volume 10 Number 09 (2021)

\title{
Evaluation of Different Gladiolus (Gladiolus grandiflorus) Cultivars in Terms of Spike Quality under Allahabad Agro Climatic Condition
}

\author{
Narendra Singh Solanki ${ }^{1,2}$, Parmanand Sen $^{3}$, Lal Singh ${ }^{4}$ and Ramshankar Pawak \\ ${ }^{1}$ Department of Horticulture, SHIATS, Allahabad (U.P.), India \\ ${ }^{2}$ District Rajgarh (Biaora) EPCO Bhopal (M.P.), India \\ ${ }^{3}$ Rural Horticulture Extension officer, Sonkatch District Dewas, M.P., India \\ ${ }^{4}$ Department of Horticulture, Krishi Vigyan Kendra Rajgarh, M.P., India \\ ${ }^{5}$ NFSM, Up Sanchalak Krishikaryalaya Rajgarh, M.P., India \\ *Corresponding author
}

\section{A B S T R A C T}

Keywords

Gladiolus,

Gladiolus

grandiflorus,

growth and yield

parameters

Article Info

Accepted:

15 August 2021

Available Online:

10 September 2021
The present experiment was conducted during October 2011 - April 2012 in the Department of Horticulture, Sam Higginbottom Institute of Agriculture Technology and Science, Allahabad, (U.P.). The experiment of design was randomized block design consisting 11 treatment with 3 replication, with a view to find out the overall performance of different cultivars of Glodiolus viz. Panjab Morning $\left(\mathrm{T}_{1}\right)$, Green Bay $\left(T_{2}\right)$, Noualux blue $\left(T_{3}\right)$, American Beauty $\left(T_{4}\right)$, Priscilla $\left(T_{5}\right)$, White Prosperity $\left(T_{6}\right)$ Red Majesty $\left(\mathrm{T}_{7}\right)$, Summer Shunshine $\left(\mathrm{T}_{8}\right)$ Delhi local $\left(\mathrm{T}_{9}\right)$, Noualux $\left(\mathrm{T}_{10}\right)$, Candyman $\left(\mathrm{T}_{11}\right)$.. On the basis of different growth and yield parameters the maximum days for first floret durability (6.16). were recorded by White Prosperity $\left(\mathrm{T}_{6}\right)$ followed by American Beauty $\left(\mathrm{T}_{4}\right)(5.76)$. The maximum number of spike length $(95.13 \mathrm{~cm})$ was obtained in White Prosperity $\left(\mathrm{T}_{6}\right)$ followed by Red Majesty $\left(\mathrm{T}_{7}\right)$ (94.16). The maximum weight of spike $(64.40 \mathrm{~g})$ was observed in White Prosperity $\left(\mathrm{T}_{6}\right)$ followed by American Beauty $\left(\mathrm{T}_{4}\right)(64.33 \mathrm{~g})$. The maximum floret diameter $(12.63 \mathrm{~cm})$ was found in Summer Pearl $\left(\mathrm{T}_{8}\right)$ followed by White Prosperity $\left(\mathrm{T}_{6}\right)(12.53 \mathrm{~cm})$. The maximum number of floret per spike (18.00) was found in White Prosperity $\left(\mathrm{T}_{6}\right)$ followed by American Beauty $\left(\mathrm{T}_{4}\right)$ (17.73). The maximum number of spikes per plant (5.33) was observed in Delhi Local $\left(\mathrm{T}_{9}\right)$ followed by White Prosperity $\left(\mathrm{T}_{6}\right)$ (1.3). Which can be recommended for cultivation in Allahabad agro-climatic condition.

\section{Introduction}

Flowers are grown and admired by human beings wherever they live. In India, the various Horticultural activities includes flower trade, bedding plant industry, plant rental services, floral perfumes, flower seeds and dry flower industry, etc. The changing lifestyle of Indians with a tendency to "say it with flowers" and celebration of festivals like 
Valentines day, Christmas, Mother's day has created a tremendous demand of cut flowers like rose, carnation, gerbera, gladiolus, tuberose. Gladiolus, belonging to sub family Ixioxideae and family Iridaceae, is a glamorous ornamental bulbous plant of both beauty and perfection. The name Gladiolus, was originally coined by Pliny The Elder (A.D. 23-79) deriving from the Latin word gladius, meaning a sword on account of the sword like shape of its foliage. Gladiolus is commonly called sword Lily. Gladiolus is principally a native of South Africa and Europe.

There are about 226 recorded species of Gladiolus scattered in Natal of Good Hope in the Republic of South Africa. Certain species are also native of countries like Ethiopia, Rhodesia, Malawi, Macarena Islands, Mediterranean region, Italy, the Balkans, France, England, Middle East and Armenia and Caucasus region of U.S.S.R. The modern garden cultivars (numbering about 30,000) have been developed through natural and man-made crosses involving about 23 species (Arora et al., 2002).

Keeping the above points in view, the present study entitled "Performance of different cultivars of gladiolus (Gladiolus grandiflorus) under Allahabad Agro-climatic conditions" was carried out in the Department of Horticulture, Allahabad School of Agriculture, Sam Higginbottom Institute of Agriculture, Technology and Science, Allahabad, in the year $2011-2012$.

\section{Materials and Methods}

The present experiment was conducted during October 2011 - April 2012 in the Department of Horticulture, Sam Higginbottom Institute of Agriculture Technology and Science, Allahabad, (U.P.). The experiment of design was randomized block design consisting 11 treatment with 3 replication, with a view to find out the overall performance of different cultivars of Glodiolus viz. Panjab Morning $\left(T_{1}\right)$, Green Bay $\left(T_{2}\right)$, Noualux blue $\left(T_{3}\right)$, American Beauty $\left(\mathrm{T}_{4}\right)$, Priscilla $\left(\mathrm{T}_{5}\right)$, White Prosperity $\left(\mathrm{T}_{6}\right)$ Red Majesty $\left(\mathrm{T}_{7}\right)$, Summer Shunshine $\left(\mathrm{T}_{8}\right)$ Delhi local $\left(\mathrm{T}_{9}\right)$, Noualux $\left(\mathrm{T}_{10}\right)$, Candyman $\left(\mathrm{T}_{11}\right)$ On the basis of different growth and yield parameters the maximum days for first floret durability were recorded by White Prosperity followed by American Beauty.

The maximum number of spike length was obtained in White Prosperity followed by Red Majesty. The maximum weight of spike was observed in White Prosperity followed by American Beauty. The maximum floret diameter was found in Summer Pearl followed by White Prosperity.

The maximum number of floret per spike was found in White Prosperity followed by American Beauty. The maximum number of spikes per plant was observed in Delhi Local followed by White Prosperity. The recorded data on the selected parameters were set for statistical analysis. The mean for collected data for each treatment was calculated.

\section{Results and Discussion}

\section{First floret durability (Days)}

The maximum days for first floret durability (6.16) was found in White Prosperity $\left(\mathrm{T}_{6}\right)$ followed by American Beauty $\left(\mathrm{T}_{4}\right)$ (5.76). While minimum days for first floret durability (3.73) was observed in Delhi Local $\left(\mathrm{T}_{9}\right)$.

\section{Spike length (cm)}

The maximum spike length $(95.13 \mathrm{~cm})$ was obtained in White Prosperity $\left(\mathrm{T}_{6}\right)$ followed by Red Majesty $\left(\mathrm{T}_{7}\right)$ (94.16) minimum spike length (64.60) was obtained in Delhi Local 
$\left(T_{9}\right)$. These findings were in conformity with those of John et al., (1996).

\section{Weight of spike (g)}

An analysis of the data clearly shows that maximum weight of spike $(64.40 \mathrm{~g})$ was observed in White Prosperity $\left(\mathrm{T}_{6}\right)$ followed by American Beauty $\left(\mathrm{T}_{4}\right)$ (64.33g). However minimum weight of spike $(37.37 \mathrm{~g})$ was observed in Delhi Local $\left(\mathrm{T}_{9}\right)$.

\section{Floret diameter $(\mathbf{c m})$}

An analysis of the data clearly shows that maximum floret diameter $(12.63 \mathrm{~cm})$ was found in Summer Pearl $\left(\mathrm{T}_{8}\right)$ followed by White Prosperity $\left(\mathrm{T}_{6}\right) \quad(12.53 \mathrm{~cm})$ and minimum floret diameter (6.90) was found in Delhi Local $\left(\mathrm{T}_{9}\right)$.

\section{Number of florets/spike}

A study of the data reveals that maximum number of floret per spike (18.00) was found in White Prosperity $\left(\mathrm{T}_{6}\right)$ followed by American Beauty $\left(\mathrm{T}_{4}\right)$ (17.73) and minimum number of florets/spike (12.93) was found in Novalux $\left(T_{10}\right)$. These findings were in conformity with those of Swain et al., (2008).

\section{Number of spikes/plant}

An analysis of the data clearly shows that maximum number of spikes per plant (5.33) was observed in Delhi Local $\left(\mathrm{T}_{9}\right)$ followed by White Prosperity $\left(\mathrm{T}_{6}\right) \quad$ (1.3). However minimum weight of spike (1.46) was observed in Green Bay $\left(\mathrm{T}_{2}\right)$. These findings were in conformity with those of Misra et al., (1988).

The basis of the results obtained, it is concluded that out of 11 cultivars. The maximum days for first floret durability (6.16). The maximum spike length $(95.13 \mathrm{~cm})$ was obtained in White Prosperity $\left(\mathrm{T}_{6}\right)$ followed by Red Majesty ( $\left.\mathrm{T}_{7}\right)$ (94.16) maximum weight of spike (64.40 g) was observed in White Prosperity $\left(\mathrm{T}_{6}\right)$.

The maximum floret diameter $(12.63 \mathrm{~cm})$ was found in Summer Pearl $\left(\mathrm{T}_{8}\right)$ and minimum floret diameter (6.90) was found in Delhi Local $\left(T_{9}\right)$. The maximum number of floret per spike (18.00) was found in White Prosperity $\left(\mathrm{T}_{6}\right)$ and minimum number of florets/spike (12.93) was found in Novalux $\left(\mathrm{T}_{10}\right)$. The maximum number of spikes per plant (5.33) was observed in Delhi Local $\left(\mathrm{T}_{9}\right)$ was observed in White Prosperity $\left(\mathrm{T}_{6}\right)$ (1.3). under Allahabad, agro-climatic condition.

Fig.1

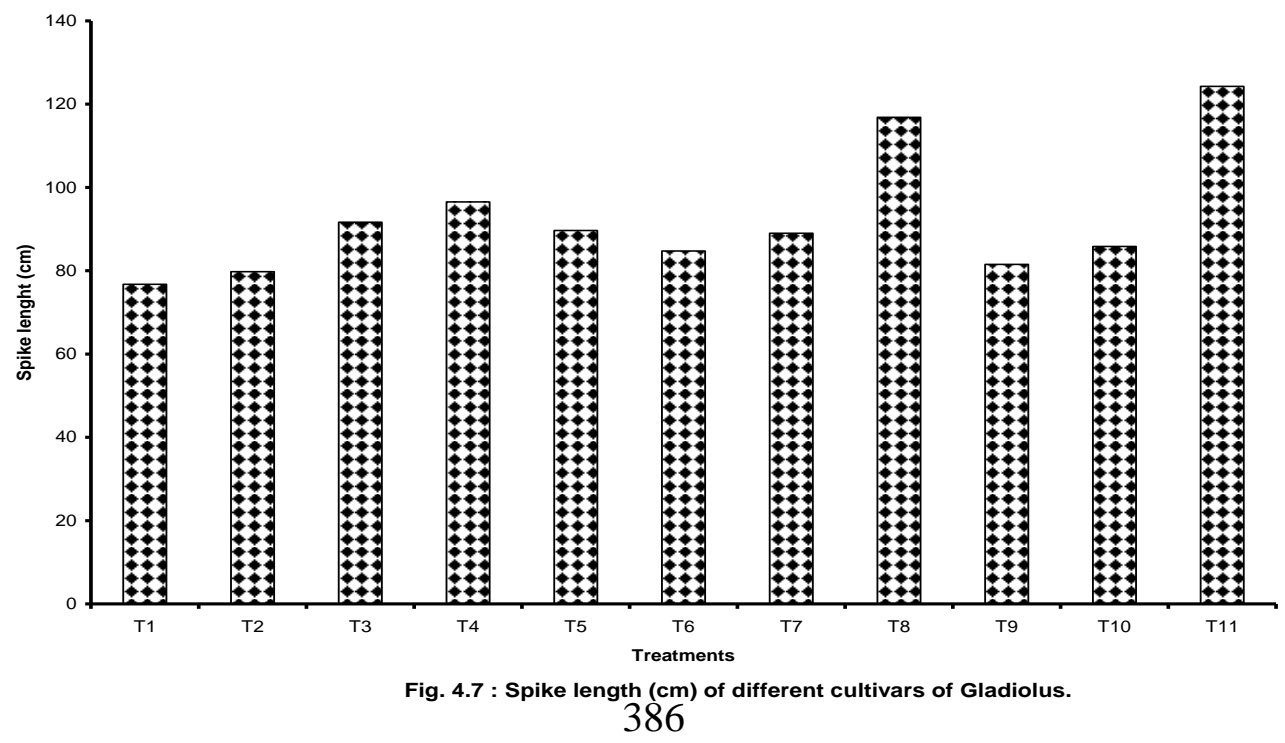


Table.1 Performance of different cultivars of gladiolus on different parameters

\begin{tabular}{|c|c|c|c|c|c|c|}
\hline Cultivars & $\begin{array}{c}\text { First floret } \\
\text { durability } \\
\text { (Days) }\end{array}$ & $\begin{array}{l}\text { Spike length } \\
\quad(\mathrm{cm})\end{array}$ & $\begin{array}{l}\text { Weight of } \\
\text { spike }(g)\end{array}$ & $\begin{array}{l}\text { Floret diameter } \\
\qquad(\mathrm{cm})\end{array}$ & $\begin{array}{l}\text { Number of } \\
\text { florets/spike }\end{array}$ & $\begin{array}{l}\text { Number of spikes/ } \\
\text { plant }\end{array}$ \\
\hline Punjab Morning & 4.86 & 76.73 & 41.86 & 11.76 & 15.33 & 1.66 \\
\hline Green Bay & 4.80 & 79.80 & 51.06 & 10.76 & 16.80 & 1.46 \\
\hline Novalux Blue & 5.13 & 91.66 & 53.86 & 12.23 & 13.80 & 1.73 \\
\hline American Beauty & 5.76 & 96.53 & 64.33 & 12.00 & 17.73 & 1.60 \\
\hline Pricilla & 4.86 & 89.66 & 52.86 & 11.46 & 16.80 & 1.66 \\
\hline White Prosperity & 6.16 & 84.73 & 64.40 & 12.53 & 18.00 & 1.93 \\
\hline Red Majesty & 4.66 & 89.00 & 54.73 & 12.46 & 17.46 & 1.80 \\
\hline Summer Sunshine & 5.20 & 116.86 & 53.33 & 12.63 & 17.53 & 1.63 \\
\hline Delhi Local & 3.73 & 81.53 & 37.37 & 6.90 & 13.06 & 5.33 \\
\hline Novalux & 4.80 & 85.86 & 57.00 & 12.50 & 12.93 & 1.80 \\
\hline Candy man & 4.80 & 124.26 & 58.40 & 12.53 & 17.26 & 1.53 \\
\hline SE & 0.447 & 4.319 & 4.735 & 0.447 & 1.272 & 0.382 \\
\hline CD & 0.933 & 9.011 & 9.879 & 0.934 & 2.655 & 0.798 \\
\hline
\end{tabular}


Fig.2

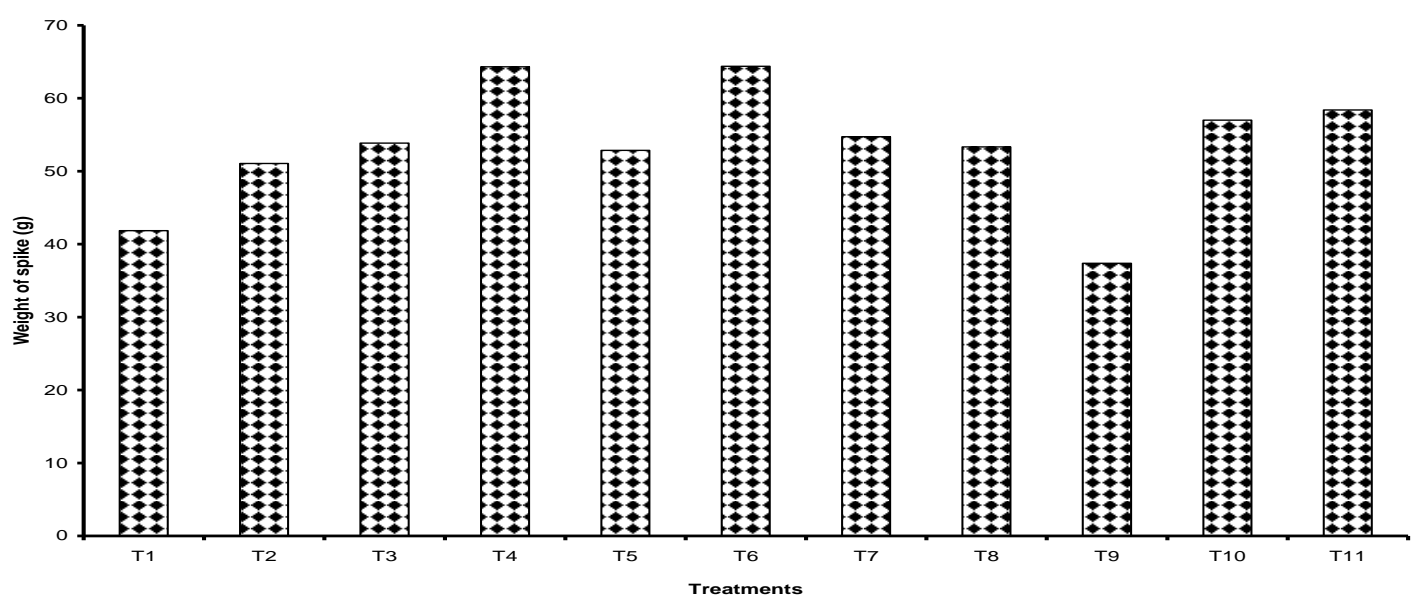

Fig. 4.8: Weight of spike (g) of different cultivars of Gladiolus.

Fig.3

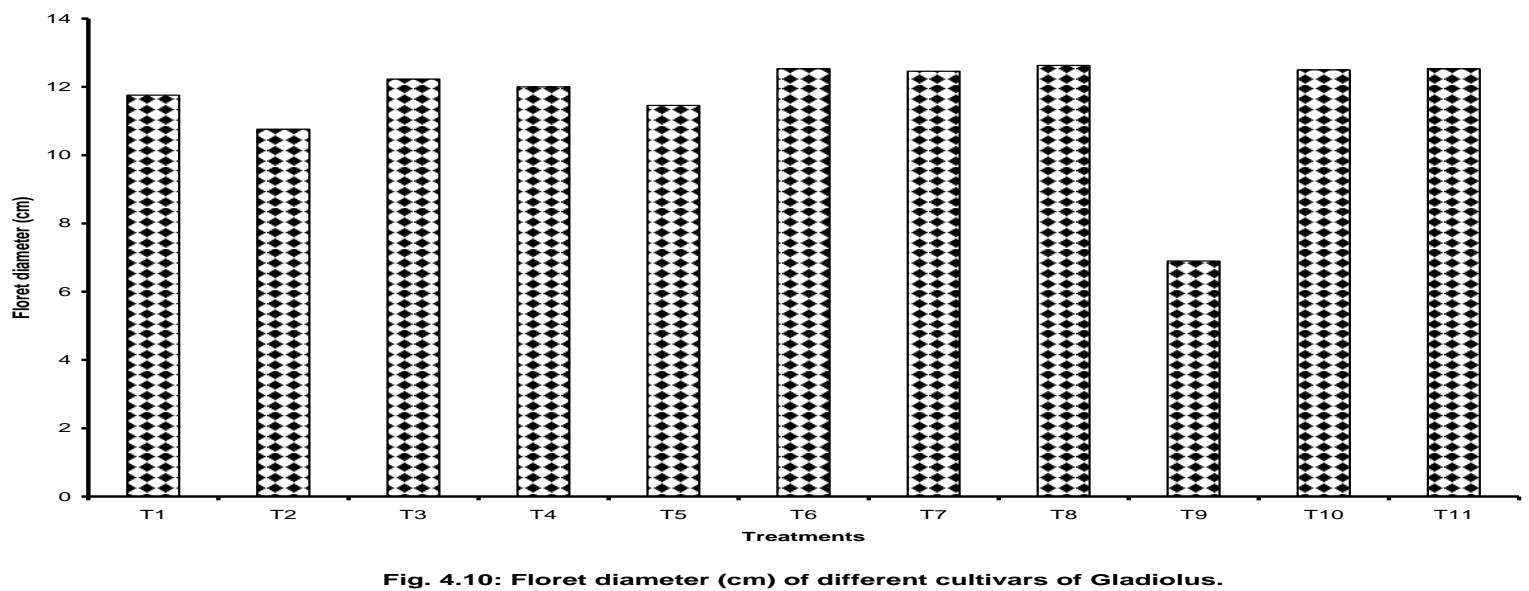

Fig.4

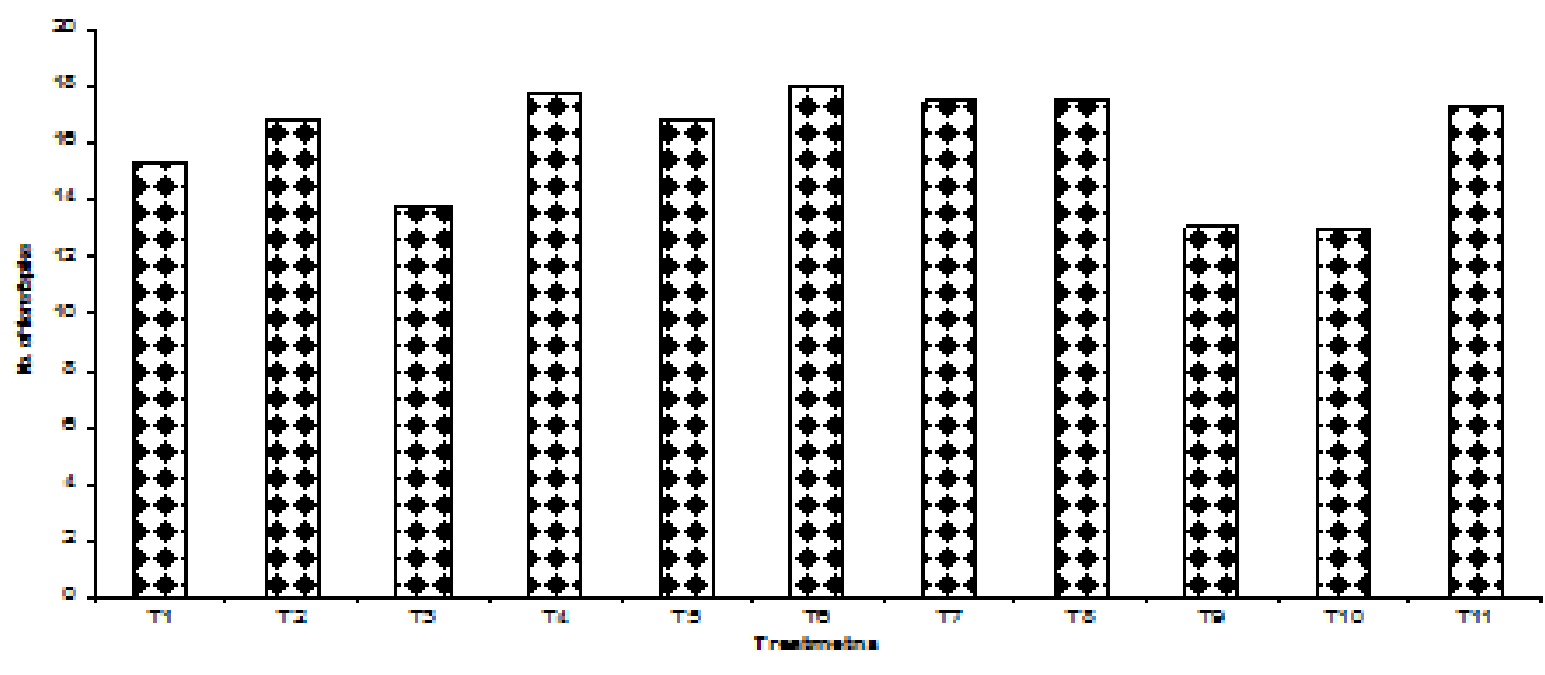

Fild 4.9: Number of ti oret/s pike of d fierent cult/vars of Clad olus. 
Fig.5

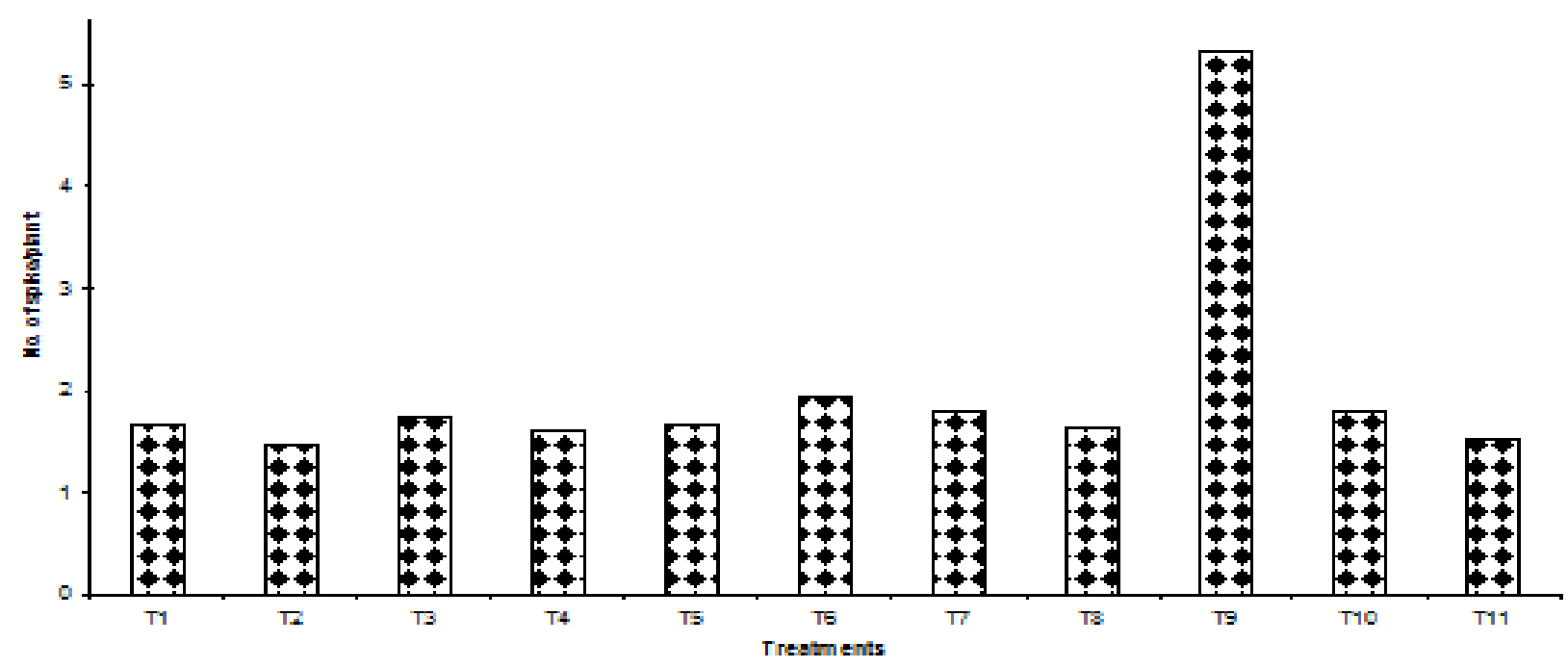

Fig-4 - 11: Num ber of s pikel pla n t of different oultivars of Oladiolus.

\section{References}

Dalal, S. R. Paithankar, D. N. Anokar, D. N. Lande, S. S. (2006). Response of gladiolus varieties to different planting dates under Akola conditions. Annals of Plant Physiology. 20: 1,137-138.

Jhon, A. Q.; Bichoo, G. A. and Siddique, M. A. (1996). Performance of gladiolus cultivars in Kashmir. Flora and. Fauna, Jhansi, 2 (1): 75 -77.

Pragya Ranjan, J. K. Attri, B. L. Das, B. Hare Krishna Ahmed, N.(2010). Performance of gladiolus genotypes forcut flower and corm production under high altitude of Uttarakhand. Ind. J. of Hort. 67: Special Issue, 386390.

Swain, S. C. Rath, S. Sethi, B. K. (2008). Evaluation of gladiolus cultivars for quality flowers and corm yield under Eastern Ghat high land zone of Orissa.Ori. J.of Hort.,36:1,120123.

Mollah, M. S. khan, F. N. and Amin, M. M (2002). Gladiolus. Landscape, Ornamental and floriculture division. HRC, BARI, Gazipur, Bangladesh. pp.13-14.

Arora, J. S.; Misra, R. L.; Singh, K.; Singh, P. and Bhattacharjee, S. K. (2002). Gladiolus. Technical Bulletin, No. 14, PP 1-3. All India Coordinated Research Project on Floriculture. Division of Floriculture and Landscaping, Ind. Agric. Res. Inst., New

Delhi. Misra, R. L. and Saini, H. C. (1988). Genotypic and phenotypic variability in gladiolus. Ind. J. of Hort., 45 (1-2): 148-152.

Pandey, R. K. Sheetal Dogra Sharma, J. P. Shivani Jamwal (2009). Performance of gladiolus cultivars under Jammu conditions. J. of Plant Sci. Res. 25: 1, 115-117. 10.

Shiramagond, M. S. and Hanamashetti, S. I. (1999). Evaluation of varieties of gladiolus under Ghataprabha Commaiid Area. Karnataka J. of Agril. Scie. 12 (1- 4): 159 -163.

Cantor et al., (2000) Studies in Romania and France to compare 26 gladiolus cultivars. Data are presented on colour, flowering date, plant height, length of 
flower stem number and size of flowers, reproduction capacity and aesthetic value.

Solanki, N. S. Kumar, M.Singh, D. (2019) Studies on morphological characters of gladiolus cultivars under Allahabad agroclimatic conditions J. of Pharmacognosy and Photochemistry
SP 5; 115-119.

Jagdish, Solanki, N. S. Kumar, M. (2018) Performance of different cultivars of gladiolus under allahabad agroclimatic conditions J. of Pharmacognosy and Phytochemistry SP 4; 27-29.

\section{How to cite this article:}

Narendra Singh Solanki, Parmanand Sen, Lal Singh and Ramshankar Pawak. 2021. Evaluation of Different Gladiolus (Gladiolus grandiflorus) Cultivars in Terms of Spike Quality Under Allahabad Agro Climatic Condition. Int.J.Curr.Microbiol.App.Sci. 10(09): 384-390. doi: https://doi.org/10.20546/ijcmas.2021.1009.044 